\title{
Visual Quality and Morphological Responses of Rosemary Plants to UV-B Radiation and Salinity Stress
}

\author{
Abolghasem Hamidi-Moghaddam ${ }^{1}$, Hossein Arouiee ${ }^{1 *}$, Nasrin Moshtaghi ${ }^{2}$, \\ Majid Azizi', Mahmoud Shoor', Fatemeh Sefidkon ${ }^{3}$ \\ 1 Department of Horticulture and Landscape Engineering, Faculty of Agriculture, Ferdowsi University of \\ Mashhad, Mashhad, Iran \\ 2 Department of Crop Biotechnology and Breeding, Faculty of Agriculture, Ferdowsi University of Mashhad, \\ Mashhad, Iran \\ ${ }^{3}$ Research institute of Forests and Rangelands, Agricultural Research, Education and Extension Organization \\ (AREEO), Tehran, Iran \\ * Corresponding author's e-mail: aroiee@um.ac.ir
}

\begin{abstract}
In order to understand the effects of ultraviolet-B (UV-B) radiation and salinity stress on the visual quality and morphological parameters, one-year-old seedlings of rosemary (Rosmarinus officinalis L.) were grown under three UV-B levels $\left(0,4.32,6.05 \mathrm{~kJ} \mathrm{~m}^{-2} \mathrm{~d}^{-1}\right)$ and four salinity regimes (Control, 50, 100 and $150 \mathrm{mM} \mathrm{NaCl}$ ) under greenhouse conditions. The results showed that enhanced UV-B radiation increased visual quality, growth index, plant biomass, shoot/root ratio, number of branches and leaves, leaf fresh and dry weight, leaf area index, specific leaf area, leaf thickness. The UV-B radiation had no significant effect on root length; however, shoot height, length of axillary shoots, length of inter node, leaf area, leaf length and width and concentration of chlorophyll $b$ were negatively impacted by the UV-B radiation. On the other hand, salinity caused a significant decrease in plant biomass, root length, shoot height, shoot/root ratio, length of axillary shoots, length of inter node, number of branches and leaf area, leaf area index, leaf length and width, leaf fresh and dry weight, specific leaf area and concentration of Photosynthetic pigments. However, the number leaves and leaf thickness significantly increased under $\mathrm{NaCl}$ salinity treatments. Visual quality and growth index were hardly affected by increasing salinity until $100 \mathrm{mM}$, but declined clearly at $150 \mathrm{mM} \mathrm{NaCl}$ salinity. The interaction between UV-B irradiation and salinity showed that pre-treatment with UV-B irradiation alleviated the harmful effects of $\mathrm{NaCl}$ and improved the visual quality rosemary plants.
\end{abstract}

Keywords: aesthetic value, chlorophyll, growth index, leaf area index, ultraviolet radiation

\section{INTRODUCTION}

The levels of UV-B radiation reaching the Earth's surface have increased during the last decades due to the depletion of the ozone layer, reduction of cloudiness and other factors (McKenzie et al., 2011). Plants due photosynthesis, are exposed to high levels solar ultraviolet radiation. However, a small increase in the UV-B radiation can have significant biological effects because UV-B is readily absorbed by a number of important macromolecules such as nucleic acids, proteins, lipids and phytohormones (Kataria et al., 2015) and lead to photo-oxidative damage and effects on plant morphology, physiology and development (Passaglia et al., 2009). On the other hand, rather than being a stressor, ultraviolet $\mathrm{B}$ acts as a morphogenetic signal in plants, resulting in decreases in stem elongation, increases in axillary branching, altered root:shoot ratio and structure of the inflorescence (Robson et al., 2015; Roro et al., 2017).

Salinity in soil or water is one of the most serious environmental problems in the cultivation 
of ornamental plants in urban areas, especially in the arid and semiarid regions of the world where potable water supply is limited (Salachna and Piechocki, 2016). Therefore, non-potable water may play an important role for landscape irrigation (Niu and Rodriguez., 2007). It is well-known that high salt concentration in the soil causes water deficit, toxicity of salt ions, nutrient imbalance, membrane damage, altered levels of growth regulators, enzymatic inhibition, etc. Particularly, in landscape plants, salinity caused foliar damage (Niu and Cabrera, 2010) which could lead to a reduction in the plant visual quality (Mahajan and Tuteja, 2005; pessarakli, 2010). On the other hand, salinity stress in some cases has favorable effects on crop yield and quality in some floricultural crops (Niu and Rodriguez, 2007) because for ornamental plants, maximum growth is often undesirable and the aesthetic value is more important (Niu and Rodriguez., 2007; Salachna and Piechocki, 2016). Therefore, the visual quality is an important factor for evaluation salt tolerance of landscape plants (Niu and Cabrera, 2010). However, the effect of salt stress on plants depends on the organ of the plant, developmental stage of the plant, genotypes of the plant species, as well as the intensity and duration of the stress and other environmental factors (Pessarakli, 2010).

As a sessile organism, plants have to encounter more than one stress simultaneously, such as unfavorable temperature, nutrient stress, drought, salinity, high ultraviolet radiation, etc., but the effects of these combined stresses on plants are still largely unknown. Interestingly, one possible consequence of co-occurring stress factors is that plants that are able to defend themselves facing one stress can become more resistant to other stresses. This phenomenon is called crosstolerance, showing that plants have a powerful regulatory system that allows them to adapt quickly to a changing environment. (Suzuki et al., 2012; Ben Rejeb et al., 2014). Under experimental conditions, ultraviolet radiation can lead to either increased or decreased sensitivity of plants to other environmental factors. (Dubé \& Bornman, 1992; Hofmann et al., 2003). Some studies suggest that plants could benefit from cross-tolerance when salinity and ultraviolet are applied simultaneously (Fedina et al.,2003; Radyukina et al.,2012; Ouhibi et al.,2014).

Rosemary (Rosmarinus officinalis L.) is an evergreen, perennial, shrubby plant belonging to the Lamiaceae family that originates from the
Mediterranean region. It has been widely cultivated since the ancient times as a landscape plant and potted florist's crop (Tounekti et al., 2008; Mateu-Andrés et al., 2013).

Several experiments were designed to examine the effects of the salinity stress (Alarcón et al., 2006; Kiarostami et al., 2010; Tounekti et al., 2011; Ershad Langroudi and Sedaghathoor, 2012; Hejazi Mehrizi et al., 2012; Abd El Lateef Gharib et al., 2014) and ultraviolet B radiation (Nogues and Baker, 2000; Grammatikopoulos et al., 2001; Luis et al., 2007) on rosemary plant; however, no research has been conducted on the interaction between ultraviolet $\mathrm{B}$ radiation and $\mathrm{NaCl}$ stress on visual quality and morphological parameters of rosemary plants. It can be hypothesized that the combination of these stress factors will result in cross-tolerance mechanisms in plants, compared to the effects of one of these stress factors alone. Therefore, the aim of this study was to examine whether different ultraviolet $\mathrm{B}$ radiation levels would affect growth of rosemary seedlings, and whether these effects would improve the visual quality and tolerance of this species to salinity.

\section{MATERIALS AND METHODS}

In order to evaluate the effects of the UV-B radiation and salinity stress on visual quality and some morphological characteristics of the rosemary plant, an experiment was conducted in a split-plot arrangement in Randomized Complete Design (RCD) with four replications in the experimental greenhouse of the Department of Horticulture Sciences, Ferdowsi University of Mashhad, Iran. The experimental treatments involved UV-B irradiation in three levels $(0,4.32$, $\left.6.05 \mathrm{~kJ} \mathrm{~m}^{-2} \mathrm{~d}^{-1}\right)$ assigned to main plots, salinity stress in four levels (tap water as control, 50, 100 and $150 \mathrm{Mm} \mathrm{NaCl}$ ) as a subplot. The UV-B radiation was provided by UV fluorescent lamps (TL $40 \mathrm{~W} / 12 \mathrm{RS}$, with a peak at $313 \mathrm{~nm}$; Phillips, Germany). The lamps were wrapped with $0.127 \mathrm{~mm}$ cellulose diacetate foil (CA), which filters radiation below $280 \mathrm{~nm}$ (UV-C radiation). In order to avoid photo-degradation of CA by the UV radiation, they were replaced weekly. The spectral irradiance from the lamps was determined with a UV spectro-radiometer (MSS2040, MSSElectronic-Gmbh, Germany). In order to prevent the UV radiation contamination among plots, they were separated by polyester. One-year-old 
rooted cuttings of $R$. officinalis were grown in $5 \mathrm{~L}$ plastic pots containing sand. They were watered daily with half strength Hoagland's solution. The UV-B radiation treatment started after four weeks of plant acclimation to the environmental conditions of the glasshouse, whereas the salinity treatments started eight weeks after applying UV-B treatments. Sampling took place six weeks later.

In order to quantify the growth response to the UV-B radiation and salinity, plant height and two perpendicular canopy widths were recorded at first and end of experiment, and growth index was determined by the equations proposed by $\mathrm{Niu}$ et al. (2007) as follows:

$$
\begin{gathered}
\text { growth index }= \\
\text { (height }+
\end{gathered}
$$

(canopy width $1+$ canopy width 2)/2)/2

The visual quality of the rosemary plants was valued based on the method described by Niu et al. (2007) on the last day of the experiment. Each plant was given a score of 1 to 5 , where $1=$ over $50 \%$ foliage damage (salt damage: burning and discoloring) or dead; $2=$ moderate $(25-50 \%)$ foliage damage; $3=$ slight $(<25 \%)$ foliage damage; 4 = good quality with acceptable growth reduction and little foliage damage (acceptable as landscape performance); $5=$ excellent with no foliage damage.

At the end of the experiment, roots and shoots were immediately separated and washed. Subsequently, their fresh weight (FW), root length, shoot height and the number of leaves were determined. The leaf area was measured using a leaf area meter (Model LI-3100, Lincoln, Nebraska,). Due to the fact that the new growth of branches was affected simultaneously by both treatments, the number of leaves and leaf area at $10 \mathrm{~cm}$ of the stem was measured. The specific leaf area was defined as the total leaf area divided by total leaf mass for each plant. For dry weight (DW) determination, the leaves were dried naturally under suitable dry and dark conditions and roots were dried at $70^{\circ} \mathrm{C}$ for $72 \mathrm{~h}$ and weighed.

The concentrations of photosynthetic pigments were determined by using a UV/V spectrophotometer (Cecil, CE 2502, UK) and based on the method described by Lichtenthaler (1987).

The measured data were analyzed statistically by means of analysis of variance (ANOVA) using JMP 8 software (SAS Institute, Cary, NC). Whenever F statistic was significant, the differences between treatments were calculated using the Tukey's HSD range test $(p \leq 0.05)$. The standard error of means was determined as well. The data is shown as Mean $\pm \mathrm{SE}$ in the figures.

\section{RESULTS}

The statistical analysis of the results showed that growth index of rosemary plants was significantly affected by the UV-B radiation $(\mathrm{P}<0.05)$ and salinity stress $(\mathrm{P}<0.01)$. Plants grown under 4.32 and $6.05 \mathrm{~kJ} \mathrm{~m}^{-2} \mathrm{~d}^{-1} \mathrm{UV}-\mathrm{B}$ levels had relatively higher growth index than those grown under zero UV-B level. The growth index of rosemary plants was reduced by the elevated salinity (Table 2). The highest reduction in growth index was observed in $150 \mathrm{mM}$ salinity level. The interaction between UV-B radiation and salinity stress indicated $(\mathrm{P}<0.05)$ that although the enhanced level of UV-B radiation had no effect on growth index at control and $50 \mathrm{mM}$ levels of salinity, they significantly increased the growth index of rosemary plants at 100 and $150 \mathrm{mM}$ salinity levels (Table 2).

The exposure to the UV-B radiation 4.32 and $6.05 \mathrm{~kJ} \mathrm{~m}^{-2} \mathrm{~d}^{-1}$ increased the root dry weight of rosemary plants $(\mathrm{P}<0.05)$. The seedlings grown under these conditions had $8.01 \%$ and $6.09 \%$

\begin{tabular}{|c|c|c|c|c|c|c|c|c|c|c|c|}
\hline \multicolumn{2}{|c|}{ Treatment } & $\begin{array}{l}\text { Root } \\
\text { Length } \\
(\mathrm{cm})\end{array}$ & $\begin{array}{l}\text { Root } \\
\text { fresh } \\
\text { weight } \\
\text { (g) }\end{array}$ & $\begin{array}{l}\text { Root dry } \\
\text { weight } \\
\text { (g) }\end{array}$ & $\begin{array}{c}\text { Shoot } \\
\text { / Root } \\
\text { ratio }\end{array}$ & $\begin{array}{c}\text { Number } \\
\text { of } \\
\text { branches }\end{array}$ & $\begin{array}{l}\text { Length of } \\
\text { inter node } \\
\quad(\mathrm{mm})\end{array}$ & $\begin{array}{l}\text { Number } \\
\text { leaves } \\
\text { per } 10 \mathrm{~cm} \\
\text { stem }\end{array}$ & $\begin{array}{l}\text { Leaf fresh } \\
\text { weight per } \\
\text { plant }(\mathrm{g})\end{array}$ & $\begin{array}{c}\text { Leaf dry } \\
\text { weight per } \\
\text { plant (g) }\end{array}$ & $\begin{array}{l}\text { Leaf } \\
\text { area } \\
\text { index }\end{array}$ \\
\hline \multirow{3}{*}{$\begin{array}{c}\text { UV-B } \\
\left(k J \mathrm{~m}^{-2} \mathrm{~d}^{-1}\right)\end{array}$} & 0 & $40.75^{a}$ & $35.29^{b}$ & $20.72^{b}$ & $1.83^{b}$ & $31.19^{c}$ & $9.33^{a}$ & $21.5^{b}$ & $53.48^{c}$ & $20.8^{c}$ & $2.90^{\mathrm{b}}$ \\
\hline & 4.32 & $40.56^{a}$ & $37.8^{a}$ & $22.38^{a}$ & $2.00^{a}$ & $41.12^{b}$ & $8.43^{b}$ & $23.75^{a}$ & $63.21^{a}$ & $24.56^{a}$ & $3.83^{a}$ \\
\hline & 6.05 & $39.94^{a}$ & $37.38^{a b}$ & $21.99 a b$ & $1.91^{\mathrm{ab}}$ & $42.31^{a}$ & $8.39^{b}$ & $23.87^{a}$ & $60.05^{b}$ & $23.34^{b}$ & $3.67^{a}$ \\
\hline \multirow{4}{*}{$\begin{array}{c}\text { Salinity } \\
\mathrm{NaCl}(\mathrm{mM})\end{array}$} & 0 & $44.08^{a}$ & $37.84^{\mathrm{a}}$ & $21.92^{a}$ & $2.04^{a}$ & $40.00^{a}$ & $8.93^{a}$ & $22.5^{a}$ & $63.44^{a}$ & $24.64^{a}$ & $3.70^{a}$ \\
\hline & 50 & $42.25^{\mathrm{ab}}$ & $37.997^{a}$ & $22.49^{a}$ & $1.92^{a b}$ & $39.42^{a b}$ & $8.86^{a}$ & $22.7^{a}$ & $60.91^{a b}$ & $23.67^{a b}$ & $3.55^{a}$ \\
\hline & 100 & $39.92^{b}$ & $38.18^{a}$ & $22.80^{a}$ & $1.87^{a b}$ & $38.25^{b}$ & $8.36^{b}$ & $24^{a}$ & $59.42^{b}$ & $23.09^{b}$ & $3.75^{a}$ \\
\hline & 150 & $35.42^{c}$ & $33.28^{b}$ & $19.57^{b}$ & $1.83^{b}$ & $35.17^{c}$ & $8.72^{a b}$ & $23^{a b}$ & $51.89^{c}$ & $20.18^{c}$ & $2.86^{b}$ \\
\hline
\end{tabular}

Table 1. Effect of UV-B radiation and Salinity on Rosemary Root, Shoot and Leaf properties 
Table 2. Interaction between UV-B Radiation and salinity on visual quality and morphological parameters of rosemary plants

\begin{tabular}{|c|c|c|c|c|c|c|c|c|c|c|}
\hline $\begin{array}{c}\text { UV-B } \\
\left(\mathrm{kJ} \mathrm{m}^{-2} \mathrm{~d}^{-1}\right)\end{array}$ & $\begin{array}{c}\text { Salinity } \\
\mathrm{NaCl}(\mathrm{mM})\end{array}$ & $\begin{array}{l}\text { Visual } \\
\text { score }\end{array}$ & $\begin{array}{c}\text { Growth } \\
\text { index }(\mathrm{cm})\end{array}$ & $\begin{array}{c}\text { Shoot } \\
\text { fresh } \\
\text { weight }(g)\end{array}$ & $\begin{array}{l}\text { Length of } \\
\text { axillary } \\
\text { shoots } \\
(\mathrm{cm})\end{array}$ & $\begin{array}{l}\text { Leaf } \\
\text { length } \\
(\mathrm{mm})\end{array}$ & $\begin{array}{l}\text { Leaf } \\
\text { width } \\
(\mathrm{mm})\end{array}$ & $\begin{array}{l}\text { Leaf } \\
\text { thickness } \\
(\mathrm{mm})\end{array}$ & $\begin{array}{l}\text { Leaf area } \\
\text { per } 10 \mathrm{~cm} \\
\text { stem }\left(\mathrm{cm}^{2}\right)\end{array}$ & $\begin{array}{c}\text { Specific } \\
\text { leaf area } \\
\left(\mathrm{cm}^{2} \mathrm{~g}^{-1}\right)\end{array}$ \\
\hline \multirow{4}{*}{0} & 0 & $5.00^{a}$ & $67.75^{a}$ & $106.88^{\mathrm{cd}}$ & $19.44^{a}$ & $37.73^{a}$ & $4.16^{a}$ & $0.88^{e}$ & $13.81^{\mathrm{a}}$ & $35.79^{b c}$ \\
\hline & 50 & $5.00^{a}$ & $67.21 \mathrm{abc}$ & $99.46^{\text {de }}$ & $19.56^{a}$ & $37.48^{a}$ & $4.16^{a}$ & $0.89^{e}$ & $13.70^{a}$ & $35.41^{b c}$ \\
\hline & 100 & $4.00^{b c}$ & $65.64^{\text {bcd }}$ & $99.41^{\text {de }}$ & $18.24^{b}$ & $36.24^{\mathrm{a}}$ & $4.07^{a}$ & $1.04^{d}$ & $12.91^{\mathrm{a}}$ & $38.72^{a b}$ \\
\hline & 150 & $1.00^{e}$ & $61.84^{\mathrm{e}}$ & $87.56^{f}$ & $16.88^{c}$ & $31.46^{\mathrm{bcd}}$ & $3.53^{b c}$ & $1.26^{a}$ & $9.43^{\text {bcd }}$ & $31.25^{c}$ \\
\hline \multirow{4}{*}{4.32} & 0 & $5.00^{a}$ & $67.70^{a b}$ & $126.34^{a}$ & $14.59^{d}$ & $32.79^{b}$ & $3.60^{b}$ & $1.09^{c d}$ & $10.10^{\mathrm{b}}$ & $39.29^{a b}$ \\
\hline & 50 & $5.00^{a}$ & $67.89^{a}$ & $120.76^{a b}$ & $14.27^{d}$ & $32.75^{\mathrm{b}}$ & $3.58^{b}$ & $1.10^{b c d}$ & $10.03^{b}$ & $39.30^{a b}$ \\
\hline & 100 & $4.50^{\mathrm{ab}}$ & $67.09^{a b c}$ & $116.07^{\mathrm{bc}}$ & $14.05^{d}$ & $32.27^{b c}$ & $3.57^{b}$ & $1.12^{b c d}$ & $9.84^{\mathrm{bc}}$ & $40.59^{a b}$ \\
\hline & 150 & $3.25^{b c}$ & $64.69^{d}$ & $95.28^{\mathrm{ef}}$ & $13.93^{d}$ & $30.60^{c d}$ & $3.47^{b c}$ & $1.22^{a}$ & $8.96^{\mathrm{cd}}$ & $40.23^{a b}$ \\
\hline \multirow{4}{*}{6.05} & 0 & $5.00^{a}$ & $67.52^{a b}$ & $116.29^{a b c}$ & $14.29^{d}$ & $\begin{array}{c}31.47 \\
\text { bcd }\end{array}$ & $3.48^{b c}$ & $1.18^{a b c}$ & $9.29^{b c d}$ & $39.28^{a b}$ \\
\hline & 50 & $5.00^{a}$ & $67.44^{a b}$ & $115.45^{b c}$ & $14.16^{d}$ & $\begin{array}{c}31.46 \\
\text { bcd }\end{array}$ & $3.47^{b c}$ & $1.18^{a b c}$ & $9.26^{\mathrm{bcd}}$ & $39.38^{a b}$ \\
\hline & 100 & $4.75^{a b}$ & $66.84^{a b c}$ & $112.01^{b c}$ & $13.54^{d}$ & $\begin{array}{c}31.42 \\
\text { bcd }\end{array}$ & $3.46^{b c}$ & $1.19^{a b}$ & $9.20^{\mathrm{bcd}}$ & $43.00^{a}$ \\
\hline & 150 & $3.00^{d}$ & $65.20^{\text {cd }}$ & $91.60^{\mathrm{ef}}$ & $13.55^{d}$ & $30.02^{d}$ & $3.37^{c}$ & $1.27^{a}$ & $8.50^{d}$ & $40.55^{a b}$ \\
\hline
\end{tabular}

greater root dry weight, respectively (Table 1) than seedlings grown under zero. However, there was no significant difference in the root length under the UV-B radiation. On the other hand, the root length and root dry weight were negatively impacted by increasing salinity $(\mathrm{P}<0.05)$. The lowest root length and root dry weight were observed in the plants treated with $150 \mathrm{mM} \mathrm{NaCl}$ in comparison to the control (Table 1).

The UV-B radiation treatments of 4.32 and $6.05 \mathrm{~kJ} \mathrm{~m}^{-2} \mathrm{~d}^{-1}$ increased the production of biomass in rosemary plants $(\mathrm{P}<0.01)$. The plants grown under these conditions had $17.88 \%$ and $10.69 \%$ greater shoot biomass (Fig. 1) than the seedlings grown under zero (Fig. 1) On the other hand, the salinity stress reduced the shoot biomass $(\mathrm{P}<$ 0.01 ). The lowest shoot biomass was observed in the plants treated with $150 \mathrm{mM} \mathrm{NaCl}$ in comparison to control. The interaction between UV-B radiation and salinity stress showed that $(\mathrm{P}<0.01)$, UV-B treatments significantly increased the shoot biomass at 50 and $100 \mathrm{mM} \mathrm{NaCl}$ than seedlings grown under zero (Fig. 1).

Both UV-B radiation and $\mathrm{NaCl}$ salinity treatments significantly $(\mathrm{P}<0.05)$ decreased the shoot height (Fig. 1). In rosemary plants grown under zero level UV-B radiation, the shoot height gradually reduced with increasing rates of salinity, compared to control.

In relation to the shoot/root ratio and number branches, both treatments acted in an opposing manner $(\mathrm{P}<0.05)$, the plants grown under two enhanced UV-B plots had relatively greater shoot/ root ratio compared to control plants, whereas, salinity treatments decreased the shoot/root ratio (Table 1). Additionally, $6.05 \mathrm{~kJ} \mathrm{~m}^{-2} \mathrm{~d}^{-1} \mathrm{UV}-\mathrm{B}$ irradiation caused a $35.7 \%$ increase in the number of branch than zero $(\mathrm{P}<0.01)$, whereas salinity stress $(150 \mathrm{mM} \mathrm{NaCl})$ decreased $(12.07 \%)$ in relation to control (Table 1).

The length of axillary shoots and length of inter node significantly decreased under both enhanced UV-B radiation and $\mathrm{NaCl}$ salinity treatments. The interaction between UV-B radiation and salinity stress was showed that $(\mathrm{P}<0.01)$, UV-B treatments 4.32 and $6.05 \mathrm{~kJ} \mathrm{~m}^{-2} \mathrm{~d}^{-1}$ significantly moderated harmful effect of $\mathrm{NaCl}$ on length of axillary shoots (Table 2).

The leaf length and leaf width were significantly affected by the UV-B radiation and salinity stress $(\mathrm{P}<0.01)$. Plants grown under 4.32 and $6.05 \mathrm{~kJ} \mathrm{~m}^{-2} \mathrm{~d}^{-1}$ UV-B levels had relatively lower leaf length and leaf width compared to those grown under zero UV-B level. Additionally, these parameters were negatively impacted by salinity (Table 2). The lowest leaf length and leaf width was observed in $150 \mathrm{mM}$ salinity level. A significant interaction between the effects of UV-B and salt treatments was found for leaf length and leaf width $(\mathrm{P}<0.01)$. On the other hand, leaf thickness increased by increasing both UV-B radiation and salinity levels $(\mathrm{P}<0.01)$. The highest leaf thickness was observed in plant treatment by $150 \mathrm{mM}$ salinity at all levels of UV-B radiation (Table 2).

Leaf fresh and dry weight per plant were significantly affected by both treatments $(\mathrm{P}<0.01)$. 

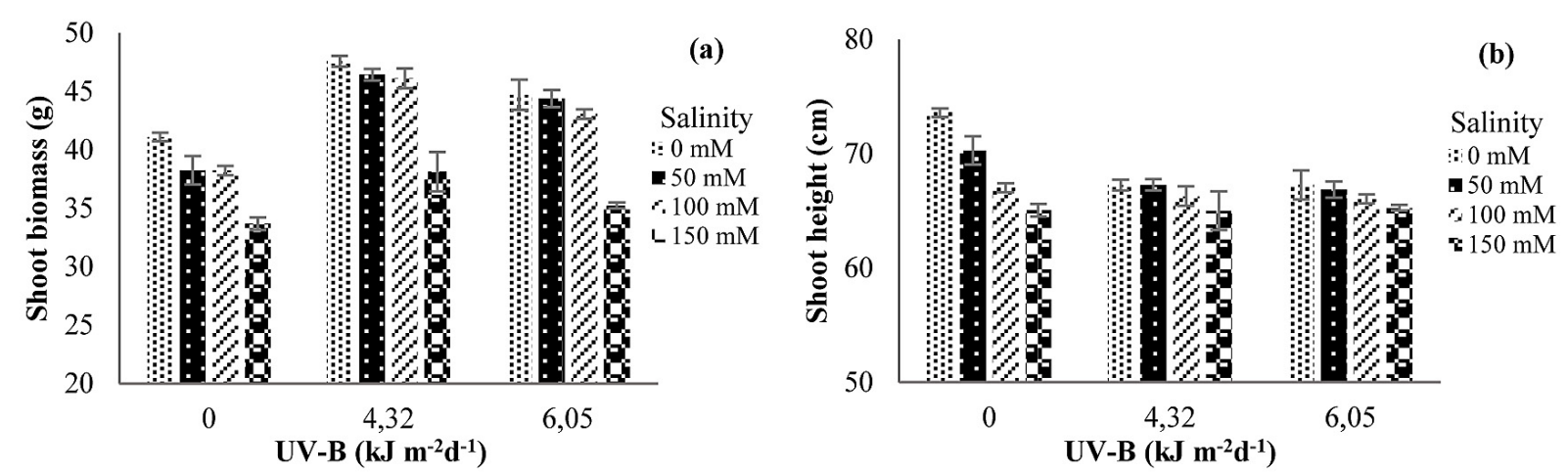

Figure 1. Interaction between UV-B Radiation and salinity on shoot biomass (a) and shoot height (b). Error bars represent the standard error.

The UV-B radiation and salinity stress acted in an opposing manner, the plants grown under enhanced UV-B plots had greater leaf fresh and dry weight compared to control plants (Table 1). The highest leaf fresh and dry weight were observed in plant grown under $4.32 \mathrm{~kJ} \mathrm{~m}^{-2} \mathrm{~d}^{-1}$. With increases of the UV-B radiation level to $6.05 \mathrm{~kJ} \mathrm{~m}^{-2} \mathrm{~d}^{-1}$, leaf fresh and dry weight relatively decreased. On the other hand, the salinity stress decreased leaf fresh and dry weight. The highest leaf fresh and dry weight were observed at control level. With increasing levels of salinity, leaf fresh and dry weight gradually decreased (Table 1).

Both UV-B radiation $(\mathrm{P}<0.01)$ and $\mathrm{NaCl}$ salinity $(\mathrm{P}<0.05)$ treatments induced a significant increase in the number leaves per $10 \mathrm{~cm}$ stem. Enhanced UV-B irradiation 4.32 and $6.05 \mathrm{~kJ} \mathrm{~m}^{-2} \mathrm{~d}^{-1}$ caused an increase 10.46 and $11.05 \%$ in number leaves per $10 \mathrm{~cm}$ stem, respectively, than zero. Whereas, salinity stress $(100 \mathrm{mM} \mathrm{NaCl})$ increased $(6.67 \%)$ its than control (Table 1$)$.

Means in each column, for each factor with the same letters are not significantly different using HSD $(\mathrm{P} \leq 0.05)$

The UV-B radiation and salinity stress reduced the leaf area per $10 \mathrm{~cm}$ stem $(\mathrm{P}<0.01)$. The plants grown under zero level of UV-B produced larger leaves than plants grown under other UV-B treatments. On the other hand, the least leaf area was observed in $150 \mathrm{mM}$ salinity level (Table 2). The plants grown under enhanced UV-B radiation 4.32 and $6.05 \mathrm{~kJ} \mathrm{~m}^{-2} \mathrm{~d}^{-1}$ levels had greater specific leaf area than the plants grown under zero UV-B level $(\mathrm{P}<0.01)$. Additionally, specific leaf area was significantly affected by salinity treatments $(\mathrm{P}<0.05)$. Plants treatment by $100 \mathrm{mM}$ salinity had relatively greater specific leaf area (Table 2). With increases salinity to $150 \mathrm{mM}$, the specific leaf area decreased; however, it was not signifi- cant compared to the plant treatment by control and $50 \mathrm{mM}$ salinity. The leaf area index was significantly affected by both treatments $(\mathrm{P}<0.01)$.

Means in each column followed by the same letters are not significantly different using HSD $(\mathrm{P} \leq 0.05)$.

The plants grown under two enhanced UV-B plots had relatively greater leaf area index than the control plants (Table 1). In contrast, $150 \mathrm{mM}$ salinity treatment decreased the leaf area index (Table 3 ). The interaction between UV-B radiation and salinity stress was shown that enhanced UV-B levels (4.32 and $6.05 \mathrm{~kJ} \mathrm{~m}^{-2} \mathrm{~d}^{-1}$ ) significantly moderated the harmful effect of $\mathrm{NaCl}$ on leaf area per $10 \mathrm{~cm}$ stem and specific leaf area (Table 2).

The effect of enhanced UV-B radiation (4.32 and $\left.6.05 \mathrm{~kJ} \mathrm{~m}^{-2} \mathrm{~d}^{-1}\right)$ in respect of chlorophyll a $(\mathrm{Chl}$ $a$ ), and total chlorophyll (T-Chl) was found nonsignificant. However, the content of chlorophyll $\mathrm{b}(\mathrm{Chl} b)$ decreased at both levels of enhanced UV-B radiation compared with zero (Fig. 2). The content of photosynthetic pigments was negatively impacted by increasing of salinity (Fig. 3 ). The plants grown under control and $50 \mathrm{mM} \mathrm{NaCl}$ produced higher concentrations of $a, b$, Total Chlorophyll and Total Carotenoids than those grown under other salinity levels.

The visual quality of rosemary was significantly affected by UV-B radiation and salinity stress $(\mathrm{P}<0.01)$. The plants grown under plots with zero level of UV-B had excellent visual scores with no foliage damage, at control and $50 \mathrm{mM}$ salinity levels (Table 1). However, leaf injury increased with rising level of $\mathrm{NaCl}$ concentration. The visual quality of plants under $100 \mathrm{mM}$ salinity levels was slightly decreased, which were acceptable as landscape performance (Table 2). With increased salinity level to $150 \mathrm{mM}$, the leaves of rosemary plants exhibited severe salt burn (over 50\% foli- 


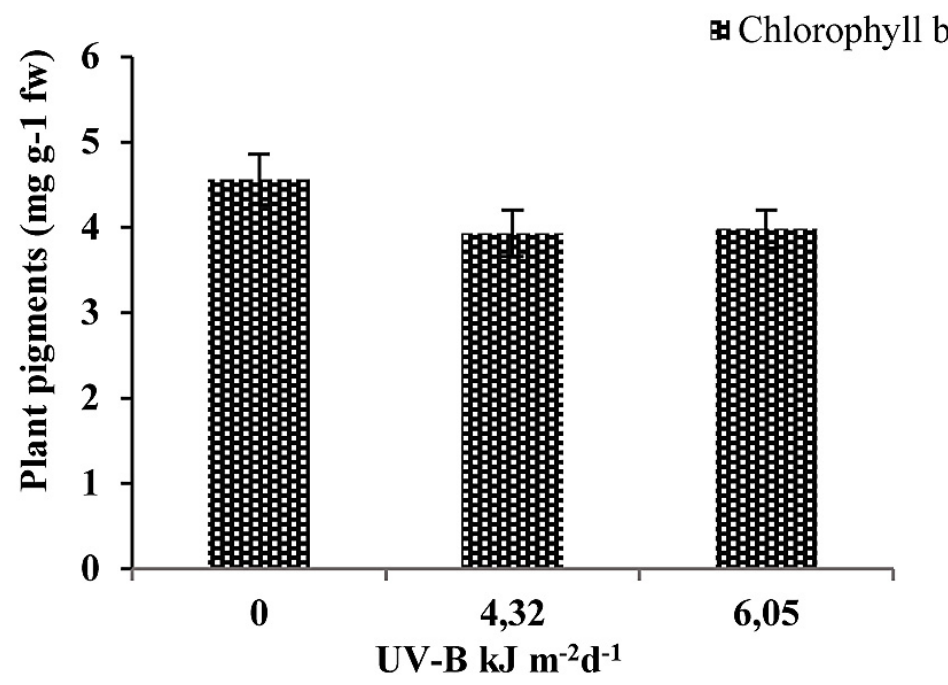

Figure 2. Effect of UV-B radiation on the Chlorophyll b concentration. Error bars represent the standard error

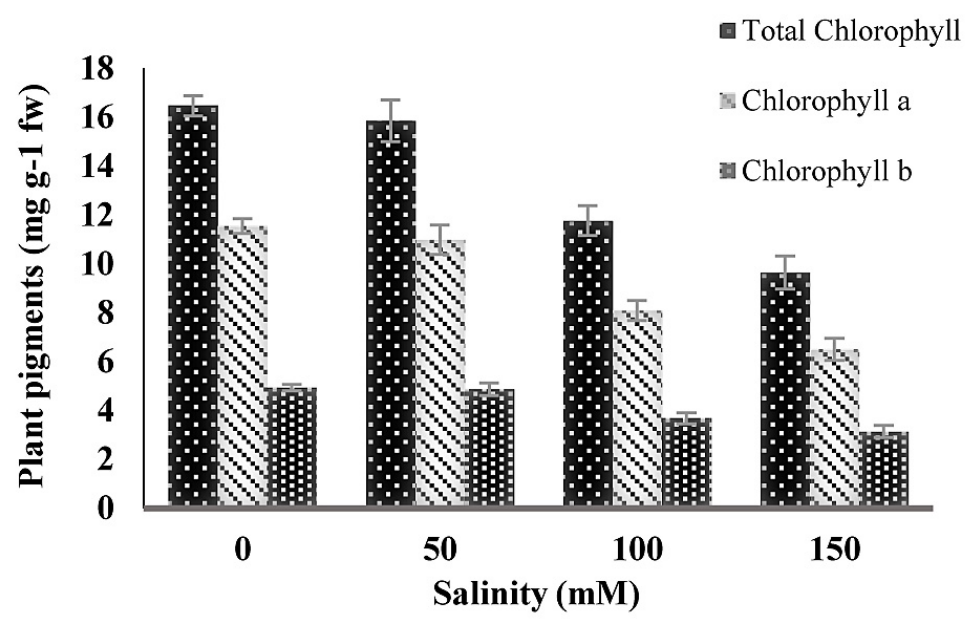

Figue 3. Effects of salinity on concentration of $a, b$ and Total Chlorophyll. Error bars represent the standard error

age damage). On the other hand, the visual quality of plants improved by UV-B radiation. In the plots with enhanced level of UV-B radiation (4.32 and $\left.6.05 \mathrm{~kJ} \mathrm{~m}^{-2} \mathrm{~d}^{-1}\right)$, plants had similar visual appearance and no differences were found in the leaves of rosemary at the control, 50 and $100 \mathrm{mM}$ salinity levels (Table 2). However, leaves of plants exhibited slight $(<25 \%)$ foliage damage at $150 \mathrm{mM}$ salinity level, which were considered acceptable for landscape.

\section{DISCUSSION}

It has been reported that UV-B-induced morphological changes, is complex due to the variations in genotype and experimental conditions (Xu \& Sullivan, 2010). A specific UV-B photo- receptor, UV RESISTANCE LOCUS 8 (UVR8), was identified (Rizzini et al. 2011). It is involved in the regulation of plant morphology, antioxidant defense system and accumulation of phenolic compounds under UV-B radiation (Hideg et al. 2013). However, the role of UVR8 in these UV-B-mediated morphophysiological changes remains poorly understood (Robson et al., 2015).

Although the sunlight does not penetrate significantly into soils, the biomass and morphology of belowground can be modified by ultraviolet $B$ radiation. Several studies were carried out on the effects of UV-B radiation on root biomass but they were contradictory, some indicating increase in response to UV-B (Rinnan et al., 2006) others - a decrease (Rinnan et al., 2005; Zaller et al., 2002). The underlying mechanisms behind these seemingly contradictory responses are not known 
but may be due to diversity of plant tissue or experimental conditions (Caldwell et al., 2007). However, in our experiment, root fresh and dry weight and shoot/root ratio slightly increased. This could be due to positive effect of UV-B radiation on shoot growth and greater allocation of resources to the root zone.

A relative decrease in shoot biomass production with increases UV-B radiation level to $6.05 \mathrm{~kJ} \mathrm{~m}^{-2} \mathrm{~d}^{-1}$, could be a consequence of lower photosynthesis and disturbances in enzyme activities and carbohydrate partitioning (Gaberscik et al., 2002). In addition, the UV-B induced changes in DNA and plant growth regulators could be probably molecular reasons for changes in plant biomass production.

It was demonstrated that indole-3-acetic acid (IAA) could be destroyed directly by ultraviolet radiation or its activity can be reduced by an interaction with the flavonoid quercetin (Hollosy, 2002 and Roro et al., 2017). These changes in IAA and ferulic acid concentrations could be the main cause of reduced cell elongation in response to UV-B (Hopkins et al., 2002). In addition, the change in plant height and branching are characteristics of loss of apical dominance, which could be caused by the reduction of IAA activity (Rozema et al., 2001). Furthermore, the UV-B radiation inhibited the shoot elongation and leaf expansion depended on UV-B modulation of GA metabolism in shoot apices and young leaves (Hayes et al., 2014 and Roro et al., 2017).

Hopkins et al. (2002) reported that the reduction in leaf growth could be due to an effect of UV-B on the rate and duration of both cell division and elongation. Zaremba et al., (1984) presumed that disruption of microtubule formation due to absorbance of UV by tubulin is one of the mechanisms that could be delayed by cell division.

Most salinity adaptive mechanisms in plants are associated with morphological and anatomical changes (Acosta-Motos et al., 2017). Cell division and elongation could be inhibited directly or indirectly by salinity (Manchanda and Garg, 2008). Plants ability to water uptake by roots inhibited by salinity and this leads to slower growth (Munns, 2005). Water deficit under saline conditions, which is caused by low osmotic potentials, could lead to decreases of cell turgor pressure. This is the major cause of inhibition of plant cell elongation under salinity (Manchanda and Garg, 2008). Reduction in cell elongation and cell division could lead to slower leaf appearance and smaller final size (Munns and Tester, 2008). Reduction in the leaf area could be considered as an avoidance mechanism, which reduces the water loss by transpiration when the stomata are closed (Acosta-Motos et al., 2017). It was also reported that salt accumulation in the old leaves accelerates cell death and thus decreases the supply of carbohydrates and plant growth regulators to the meristematic regions, consequently inhibiting growth. In fact, plant growth is decreased by a reduction in the photosynthesis rate and by an excessive uptake of salts. (Azza Mazher et al., 2007 and Acosta-Motos et al., 2017).

Reduction in the chlorophyll contents under high ultraviolet radiation may be due to the inhibition of its biosynthesis or degradation of these pigments and their precursors (Agrawal and Rathore, 2007). It has been reported that the reduction in amount of chlorophyll could be due to the effect of UV-B on expression of genes encoding for chlorophyll binding proteins (Mishra et al., 2008). Marwood and Greenberg (1996) reported that the UV-B radiation resulted in a reduction in the amount of $C h l b$ as compared to Chl $a$ and suggested that high ultraviolet radiation may lead to the selective destruction of $C h l b$ biosynthesis or degradation of its precursors. This is in agreement with the study Marwood and Greenberg (1996) and Enteshari et al. (2005) where enhanced UV-B radiation decreased chlorophyll $b$ content.

It is known that the salinity stress leads to enhancing the production of ROS (pessarakli, 2010). Accumulation of free oxygen radicals in plant cells under stress leads to peroxidation of unsaturated fatty acids of thylakoid membranes and consequently chlorophyll degradation enhanced (Miller et al., 2010). It was also reported that reduction in the amount of chlorophyll in salinized plants could be related to increased activity of the chlorophyll degrading enzyme chlorophyllase (Reddy and Vora, 1986). Kiarostami et al. (2010), Tounekti et al. (2011) Ershad Langroudi and Sedaghathoor (2012), Abd El Lateef Gharib et al. (2014) reported similar findings related to photosynthetic pigments of the Rosemary plants under salinity stress.

Reduction in the visual quality could be related to the salt ions accumulation in leaves and degradation of chlorophyll. It was reported that high salinity level causes accumulation of $\mathrm{Na}^{+}$ and $\mathrm{Cl}^{-}$ions in cells that frequently create toxicity and this lead to chlorosis and necrosis of leaves (Wahome et al., 2001; Acosta-Motos et al., 2017). 
In our experiment, the interaction between UV-B irradiation and salt stress demonstrated that rosemary plants exposed to UV-B radiation were less sensitive to salinity stress and had better visual quality than the plants not exposed to UV-B radiation. This could be due to cross-tolerance which also reported by Radyukina et al, (2012) in Artemisia (Artemisia lercheana Web.), common basil (Ocimum basilicum L.) and black cumin (Nigella sativa L.), Hamid et al., (2012) in mungbean (Vigna radiata) and Javadmanesh et al, (2012) in Mize (Zea mays L.).

It is widely accepted that co-occurring stress factors induce different signaling pathways, which share some components and common outputs. This could help plants to minimize the energy costs and create a flexible signaling network (Ben Rejeb et al., 2014). In addition, it has also been hypothesized that low ultraviolet $\mathrm{B}$ radiation leads to eustress (beneficial stress) and that stimuli specific signaling pathways pre-dispose plants to a state of low alert that includes activation of antioxidant defenses mechanisms (Hideg et al., 2013).

\section{CONCLUSIONS}

Our results showed that the rosemary plant is resistant to UV-B radiation but relatively sensitive to salinity. As previously mentioned, for ornamental plants, being compact and free of foliar damage is more important than maximum growth. Therefore, the UV-B radiation and moderate salinity may have a potential benefit of acting as a growth retardant and improved aesthetic value. The interaction between ultraviolet radiation and salt stress confirmed the opinion that pre-exposure of the rosemary plants to UV-B radiation increased the plant resistance to salinity due to the activation of similar protective mechanisms. Our results suggested that if rosemary cuttings were exposed to UV-B irradiation in nursery or greenhouse before transplanting to main location, the plant resistance to salinity stress improved due to cross-tolerance. However, further studies are required to testify this concept.

\section{REFERENCES}

1. Abd El Lateef Gharib F. Zeid I M. Salem M A H. Ahmed E Z. 2014. Effects of Sargassum latifolium Extract on Growth, Oil Content and Enzymatic Ac- tivities of Rosemary Plants under Salinity Stress. Life Science Journal, 11, 933-945.

2. Acosta-Motos J R. Ortuño M F. Bernal-Vicente A. Diaz-Vivancos P. Sanchez-Blanco M J. Hernandez J A. 2017. Plant Responses to Salt Stress: Adaptive Mechanisms. Agronomy, 7 (1), 18.

3. Agrawal S B. Rathore D. 2007. Changes in oxidative stress defense system in wheat (Triticum aestivum L.) and mung bean (Vigna radiate L.) cultivars grown with and without mineral nutrients and irradiated by supplemental Ultraviolet-B. Environmental and Experimental Botany, 59, 21-23.

4. Alarcón J J. Morales M A. Ferrández T. SánchezBlanco M J. 2006. Effects of water and salt stresses on growth, water relations and gas exchange in Rosmarinus officinalis. Journal of Horticultural Science and Biotechnology, 81, 845-853.

5. Azza Mazher A M. El-Quesni E M F. Farahat M M. 2007. Responses of ornamental plants and woody trees to salinity. World Journal of Agricultural Sciences, 3, 386-395.

6. Ben Rejeb I. Pastor V. Mauch-Mani B. 2014. Plant Responses to Simultaneous Biotic and Abiotic Stress: Molecular Mechanisms. Plants, 3, 458-475.

7. Caldwell M M. Bornman J F. Ballares C L. Flint S D. Kulandaivelu G. 2007. Terrestrial ecosystems, increased solar ultraviolet radiation, and interactions with other climate change factors. Photochemical and Photobiological Sciences, 6: 252-266.

8. Dubé S L. Bornman J F. 1992. Response of spruce seedlings to simultaneous exposure to ultraviolet$\mathrm{B}$ radiation and cadmium. Plant Physiology and Biochemistry, 30, 761-767.

9. Enteshari Sh. Kalantari Kh. Ghorbanli M. Torkzadeh M. 2005. The effect of different bands of ultraviolet radiation on pigments content in Glycine max L. Iranian Journal of Plant Biology, 18 (1), 77-84.

10. Ershad Langroudi M. Sedaghathoor S. 2012. Effect of Different Media and Salinity Levels on Growth Traits of Rosemary (Rosmarinus officinalis L.). American-Eurasian Journal Agriculture \& Environmental Science, 12 (9), 1134-1142.

11. Fedina I. Grigorova I. Georgieva K. 2003. Response of barley seedlings to UV-B radiation as affected by $\mathrm{NaCl}$. Journal of Plant Physiology, 160, 205-208.

12. Gaberscik A. Voncina M. Trost T. Germ M. Bjorn L O. 2002. Growth and production of buckwheat (Fagopyrum esculentum) treated with reduced, ambient and enhanced UV-B radiation. Journal of Photochern and Photobiol. B: Biology, 66, 30-36.

13. Grammatikopoulos G. Drilias P. Kyparissis A. Petropoulou Y. Manetas Y. 2001. Reduction of ambient UV-B radiation does not affect growth but may change the flowering pattern of Rosmarinus offici- 
nalis L. Plant Ecology, 154, 119-122.

14. Hamid N. Hussain H. Jawaid F. Rahman A. 2012. Short term exposure of UV-B radiation enhances salinity tolerance in vigna radiate. Pakistan Journal of Botany, 44 (2): 841-844.

15. Hayes S. Velanis C. N. Jenkins G I. Franklin K A. 2014. UV-B detected by the UVR8 photoreceptor antagonizes auxin signaling and plant shade avoidance. Proc. Natl. Acad. Sci. USA. 111 (32), 11894-11899.

16. Hejazi Mehrizi M. Shariatmadari H. Khoshgoftarmanesh A H. Dehghani F. 2012. Copper Effects on Growth, Lipid Peroxidation, and Total Phenolic Content of Rosemary Leaves under Salinity Stress. Journal of Agriculture Science and Technology, 14, 205-212.

17. Hideg E. Jansen M A K. Strid A. 2013. UV-B exposure, ROS, and stress: inseparable companions or loosely linked associates? Trends in Plant Science, 18, 107-115.

18. Hofmann R W. Campbell B D. Bloor S J. Swinny E E. Markham K R. Ryan K G. Fountain D W. 2003. Responses to UV-B radiation in Trifolium repens L. physiological links to plant productivity and water availability. Plant, Cell and Environment, 26, 603-612.

19. Hollosy F. 2002. Effects of ultraviolet radiation on plant cells. Micron, 33, 179-197.

20. Hopkins L. Bond M A. Tobin A K. 2002. Ultraviolet-B radiation reduces the rates of cell division and elongation in the primary leaf of wheat (Triticum aestivum L.cv. Maris Huntsman). Plant, Cell \& Environment, 25(5), 617-624.

21. Javadmanesh S. Rahmani F. Pourakbar L. 2012. UV-B Radiation, Soil Salinity, Drought Stress and Their Concurrent Effects on Some Physiological Parameters in Mize Plant. American-Eurasian Journal of Toxicological Sciences, 4 (4), 154-164.

22. Kataria S. Jajoo A. Guruprasad K N. 2015. Impact of increasing Ultraviolet-B (UV-B) radiation on photosynthetic processes. Journal of Photochemistry and Photobiology B: Biology, 137, 55-66.

23. Kiarostami Kh. Mohseni R. Saboora A. 2010. Biochemical changes of Rosmarinus officinalis under salt stress. Journal of Stress Physiology \& Biochemistry, 6, 114-122.

24. Lichtenthaler K H. 1994. Chlorophyll and carotenoids pigments of photosynthetic biomembrances. Methods in Enzymology, 148, 350-382.

25. Luis J C. Martin P R. Valdes G F. 2007. UV-B radiation effects on foliar concentrations of rosmarinic and carnosic acids in rosemary plants. Food Chemistry, 101, 1211-1215.

26. Mahajan S. Tuteja N. 2005. Cold, salinity and drought stresses: an overview. Archives of Bio- chemistry and Biophysics, 444, 139-158.

27. Manchanda, G., Garg, N., 2008. Salinity and its effects on the functional biology of legumes. Acta Physiol Plant. 30, 595-618.

28. Marwood C A. Greenberg B M. 1996. Effect of Supplementary UVB Radiation on Chlorophyll Synthesis and Accumulation of Photosystems during Chloroplast Development in Spirodela oligorrhiza. Photochemistry and Photobiology, 64 (4), 664-670.

29. Mateu-Andrés I. Aguilella A. Boisset F. Currás R. Guara M. Laguna E. Marzo A. Puche M F. Pedrola J. 2013. Geographical patterns of genetic variation in rosemary (Rosmarinus officinalis) in the Mediterranean basin. Botanical Journal of the Linnean Society, 171, 700-712.

30. McKenzie R L. Aucamp P J. Bais A F. Bjorn L O. Iyas M. Madronichg S. 2011. Ozone depletion and climate change: impacts on UV radiation. Photochemical and Photobiological Sciences, 10, 182-198.

31. Miller G. Suzuki N. Ciftci-Yilmaz S. Mittler R. 2010. Reactive oxygen species homeostasis and signalling during drought and salinity stresses. Plant, Cell and Environment, 33, 453-467.

32. Mishra V. Srivastava G. Prasad S M. Abraham G. 2008. Growth, photosynthetic pigments and photosynthetic activity during seedling stage of cowpea (Vigna unguiculata) in response to UV-B and dimethoate. Pesticide Biochemistry and Physiology, $92,30-37$.

33. Munns R. 2005. Genes and salt tolerance: bringing them together. New Phytol, 167 (3), 645-663.

34. Munns R. Tester M. 2008. Mechanisms of salinity tolerance. Annual Review of Plant Physiology, 59, 651-681.

35. Niu G. Cabrera R I. 2010. Growth and physiological responses of landscape plants to saline water irrigation: A review. HortScience, 45:1605-1609.

36. Niu G. Rodriguez D S. 2007. Salinity Tolerance of Lupinus havardii and Lupinus texensis. HortScience, 42(3): 526-528.

37. Niu G. Rodriguez D S. Aguiniga L. 2007. Growth and landscape performance of ten herbaceous species in response to saline water irrigation. Journal of Environmental Horticulture, 25: 204-210.

38. Nogues S. Baker N. 2000. Effects of drought on photosynthesis in Mediterranean plants growing under enhanced UV-B radiation. Journal of Experimental Botany, 51, 1309-1317.

39. Ouhibi C. Attia H. Rebah F. Msilini N. Chebbi M. Aarrouf J. Urban L. Lachaal M. 2014. Salt stress mitigation by seed priming with UV-C in lettuce plants: Growth, antioxidant activity and phenolic compounds. Plant Physiology and Biochemistry, $83,126-133$. 
40. Passaglia A. da Silva R. Moreno K. Jorge N. Martins C F. 2009. Development of a DNA dosimeter system for monitoring the effects of solar-ultraviolet radiation. Photochemical and Photobiological Sciences, 8, 111-120.

41. Pessarakli M. 2010. Handbook of Plant and Crop Stress. Third Edition. CRC Press.

42. Radyukina N L. Toaima V I M. Zaripova N R. 2012. The Involvement of Low_Molecular Antioxidants in Cross_Adaptation of Medicine Plants to Successive Action of UV_B Radiation and Salinity. Russian Journal of Plant Physiology, 59(1):71-78.

43. Reddy M P. Vora A B. 1986. Changes in pigment composition, hill reaction activity and saccharides metabolism in bajra (Pennisetum typhoides S\&H) leaves under $\mathrm{NaCl}$ salinity. Photosynthica, 20, 50-55.

44. Rinnan R. Gehrke C. Michelsen A. 2006. Two mire species respond differently to enhanced ultraviolet$B$ radiation: Effects on biomass allocation and root exudation, New. Phytol., 169, 809-818.

45. Rinnan R. Keinänen M M. Kasurinen A. Asikainen J. Kekki T K. Holopainen T. Ro-Poulsen H. Mikkelsen T N. Michelsen A. 2005. Ambient ultraviolet radiation in the Arctic reduces root biomass and alters microbial community composition but has no effects on microbial biomass, Glob. Change Biol., 11, 564-574.

46. Rizzini L. Favory J J. Cloix C. Faggionato D. O’Hara A. Kaiserli E. Ulm R. 2011. Perception of UV-B by the Arabidopsis UVR8 protein. Science, 332, 103-106.

47. Robson T. Klem K. Urgan O. Jansen M A k. 2015. Re-interpreting plant morphological responses to UV-B radiation. Plant Cell Environ, 38: 856-866.

48. Roro A G. Dukker S A F. Tone I M. Solhaug K A. Torre S. Olsen J. 2017. UV-B-induced Inhibition of Stem Elongation and Leaf Expansion in Pea Depends on Modulation of Gibberellin Metabolism and Intact Gibberellin Signalling. Journal of Plant Growth Regulation. 10.1007/s00344-017-9671-0.

49. Rozema J. Broekman R. Lud D. Huiskes A. Moerdijk T. de Bakker N. Meijkamp B. Van Beem A.
2001. Consequences of depletion of stratospheric ozone for terrestrial antarctic ecosystems: the response of Deschampsia antarctica to enhanced UV-B radiation. Plant Ecol, 154, 101-115.

50. Salachna P. Piechocki R. 2016. Effects of sodium chloride on growth and mineral nutrition of Purpletop vervain. Journal of Ecological Engineering, $17(2), 148-152$.

51. Suzuki N. Koussevitzky S. Mittler R. Miller G. 2012. ROS and redox signalling in the response of plants to abiotic stress. Plant Cell Environ, 35, 259-270.

52. Tounekti T. Vadel A M. Bedoui A. Khemira H. 2008. $\mathrm{NaCl}$ stress affects growth and essential oil composition in rosemary (Rosmarinus officinalis L.). Journal of Horticultural Science \& Biotechnology, 83, 267-273.

53. Tounekti T. Vadel A M. Ennajeh M. Khemira H. Munné-Bosch S. 2011. Ionic interactions and salinity affect monoterpene and phenolic diterpene composition in rosemary (Rosmarinus officinalis). Journal of Plant Nutrition and Soil Science, 174, 504-514.

54. Wahome P. Jesch H. Grittner I. 2001. Mechanisms of salt stress tolerance in two rose rootstocks: Rosa chinensis „Major" and R. rubiginosa. Scientia Horticulturae, 87, 207-216.

55. Xu C. Sullivan J H. 2010. Reviewing the technical designs for experiments with ultraviolet-B radiation and impact on photosynthesis, DNA and secondary metabolism. Journal of Integrative Plant Biology, 52, 377-387.

56. Zaller J G. Caldwell M M. Flint S D. Scopel A L. Sala O E. Ballaré C L. 2002. Solar UV-B radiation affects below-ground parameters in a fen ecosystem in Tierra del Fuego, Argentina: Implications of stratospheric ozone depletion, Glob. Change Biol, 8, 867-871.

57. Zaremba T G. LeBon T R. Millar D B. Smeljkal R M. Hawley R J. 1984. Effects of ultraviolet light on the in vitro assembly of microtubules. Biochemistry, 23, 1073-1080. 